\title{
The Sea-Leopard and the Oxyrrhynchus Shark (Ael. NA 11, 24)*
}

\section{Elwira Kaczyńska}

University of Lodz, Faculty of Philology, Chair of Classical Philology,

Dep. of Latin Studies and Linguistics, ul. Pomorska 171/173, 90-236

Łódź, Poland; elwira.kaczynska@uni.lodz.pl

\section{Krzysztof Tomasz Witczak}

University of Lodz, Faculty of Philology, Chair of Classical Philology,

Dep. of Latin Studies and Linguistics, ul. Pomorska 171/173, 90-236

Łódź, Poland; krzysztof.witczak@uni.lodz.pl

For citation: Elwira Kaczyńska, Krzysztof Tomasz Witczak. The Sea-Leopard and the Oxyrrhynchus Shark (Ael. NA 11, 24). Philologia Classica 2020, 15 (1), 37-46.

https://doi.org/10.21638/spbu20.2020.103

The paper analyzes Ch. 24 of the 11th book of Aelian's De natura animalium devoted to the so-called sea-leopard ( $\pi \alpha \dot{\rho} \rho \alpha \lambda ı \varsigma$ ) and the oxyrrhynchus fish, both living in the Red Sea. Aelian compares the body colour of the sea-leopard to the mountain leopard, i.e. the snow leopard or the ounce (Panthera uncia Schreber, 1775). This comparison clearly demonstrates that the sealeopard is to be identified with the sand tiger shark or the spotted ragged-tooth shark (Carcharias taurus Rafinesque, 1810). This fish usually resides and hunts in the depths of the sea, but also swims to the coast and sometimes attacks the swimming people. The attacks of sand tiger sharks must have taken place in ancient times, so the fish was easily recognizable not only by the Greeks but also by the inhabitants of the Red Sea's seashore. The Greek ichthyonym ó $\xi \dot{v}(\rho) \rho v \gamma \chi 0 \varsigma$ refers to five different species of fish, but Aelian uses it to denote an oriental kind of shark existing in the Red Sea $(N A 11,24)$. The oxyrrhynchus shark has an elongated mouth, golden eyes and white eyelids, i.e. nictitating membranes, typical of sharks belonging to the order Carcharhiniformes. Its tail is oblong in shape and its fins are black and white. There are also pale and green parts of its body. On the basis of Aelian's description it is possible to suggest that the unknown fish should be identified with the bignose shark (Carcharhinus altimus S. Springer, 1950).

Keywords: animal terminology, etymology, Greek language, leopards, sharks, vocabulary, zoological literature.

\section{The description by Aelian}

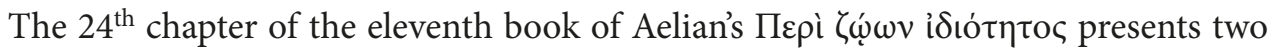
unidentified kinds of fish living in the Red Sea. The Greek text runs as follows:

* The present article is part of the research project entitled Greek-Oriental contacts in a comparative perspective, financed by the scholarly development fund of the Faculty of Philology, University of Lodz. We would like to thank Prof. Michail Pozdnev (St. Petersburg State University) and two anonymous readers for Philologia Classica for useful comments and suggestions, as well as Prof. Ephraim Lytle (University of Toronto) and Dr. Mikołaj Rychło (University of Gdańsk) for checking and improving on our English. Of course, all shortcomings are our own.

(C) St. Petersburg State University, 2020 


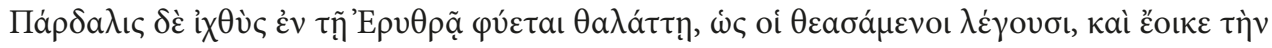

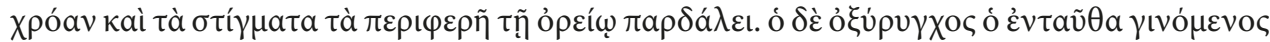

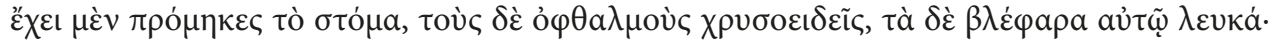

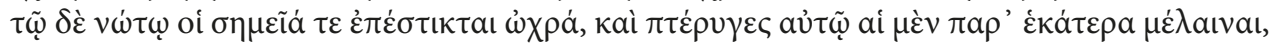

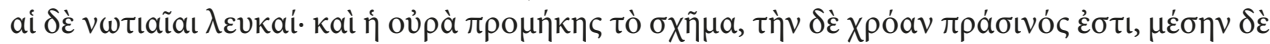

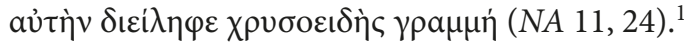

The Leopard-fish is native to the Red Sea, according to those who have seen it, and in its colour and circular markings resembles the leopard of the mountains. The Oxyrrhynchus, which occurs there, has an elongated mouth, eyes like gold, and white eyelids. There are pale markings on its back, but the fins on the either side are black, while the dorsal fins are white. Its tail is oblong in shape and its colour is green, and a streak of gold bisects it. (Transl. by Alwin F. Scholfield; partly adapted. ${ }^{2}$ )

\section{Sea-leopards in ancient sources}

The fish called $\pi \alpha \dot{\alpha} \delta \alpha \lambda \iota \varsigma$ appears in two ancient texts. Oppianus mentions it among

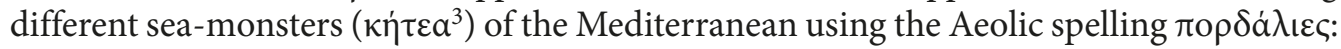

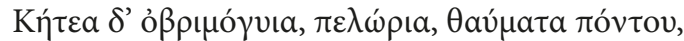

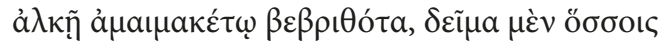

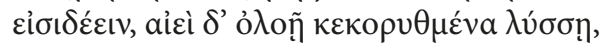

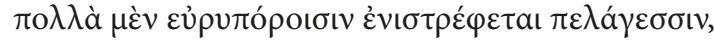

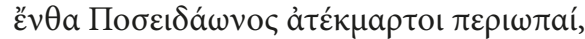

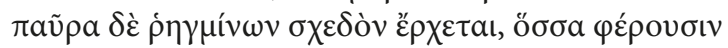

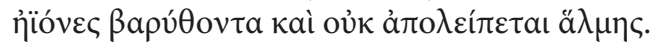

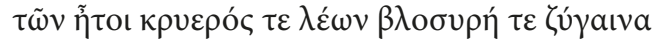

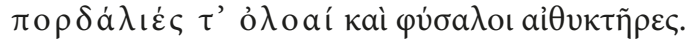

(Halieutica 1, 360-368 ${ }^{4}$ )

The Sea-monsters mighty of limb and huge, the wonders of the sea, heavy with strength invincible, a terror for eyes to behold and ever armed with deadly rage - many of these there be that roam the specious seas, where are the unmapped prospects of Poseidon, but few of them come nigh the shore, those only whose weight the beaches can bear and whom the salt water does not fail. Among these are the terrible lion [i.e. the basking shark. Cetorhinus maximus Gunnerus] and the truculent hammerhead [i.e. the smooth hammerhead, Sphyrna

${ }^{1}$ We quote the Greek text from the bilingual edition by Scholfield (1959, II 392), as well as that by Maspero (1998, II 670). We have also consulted the most recent edition by García Valdés, Llera Fueyo, Rodríguez-Noriega Guillén $(2009,272)$.

2 Scholfield 1959, II 393.

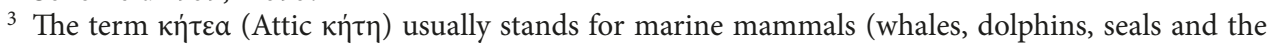
like) as well as for large viviparous fish, especially sharks (in opposition to oviparous fish), cf. Kokoszko

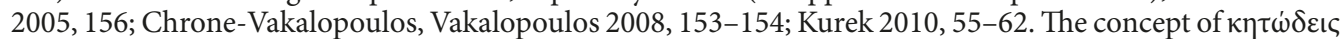
(ix $\theta \dot{v} \varepsilon \varsigma$ ) is somewhat broader, as it refers to large oviparous fish (e. g. the tunny), both marine and freshwater

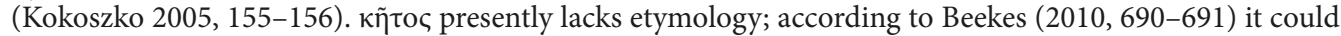
be a loan from the Pre-Greek.

${ }^{4}$ See also Opp. H. 2, 352; 3, 391; 5, 30. We quote Oppian's text from Schneider's edition, as well as

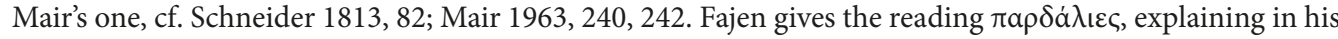
apparatus criticus that the alternative variant $\pi \mathrm{o} \rho \delta a \dot{\lambda} \iota \varepsilon \varsigma$ was suggested by Schneider (" $\pi 0 \rho \delta \dot{\alpha} \lambda \iota \varepsilon \varsigma$ proponit Schneider"), cf. Fajen 1999, 34. 
zygaena L. ], and the deadly leopards and the dashing physaloi [i.e. whales]. (Trans. by A. W. Mair, partly adapted..$^{5}$ )

Oppianus stresses the aggressive character of sea-leopards, saying that "[d]read is the bite of the Leopard of the land but that of the sea Leopard is more terrible" (Opp. Hal. 5, 30-31:

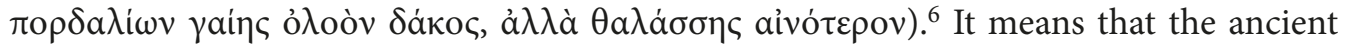
Greeks knew very well that sea-leopards attacked bathing people.

Aelian mentions a sea-leopard in a very similar description of the largest sea-monsters.

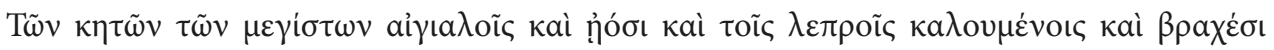

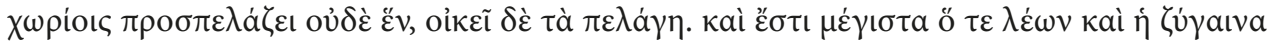

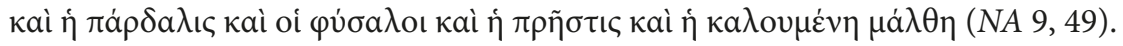

There is not one of the largest Cetaceans that comes near the shore or the beach or 'leprous' (that is, rocky) spots or into shallow water: they live in the deeps. The largest of them are the Sea-Lion, the Hammer-headed Shark, the Sea-Leopard, the great Whales, the Pristis, and the cetus called Maltha [i.e. North Atlanic right whale (Eubalaena glacialis Müller)]. (Transl. by A.F. Scholfield, adapted and augmented. ${ }^{7}$ )

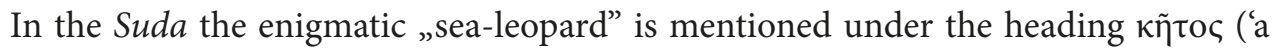
sea-monster, a large fish or a sea-mammal'):

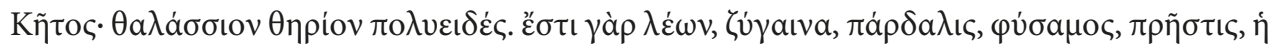

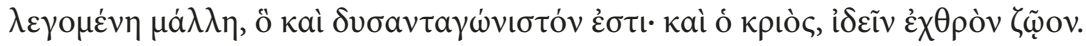

Ketos: a marine animal of different appearance. There is a sea-lion, a hammerhead, a sealeopard, a whale, a sawfish, the so-called malle, which is difficult to beat, and also the searam, a hostile animal at first glance. (Transl. is ours.)

Elsewhere, Aelian, probably referring to the Indica by Megasthenes (Fr. 59), ${ }^{8}$ seems to indicate the existence of "sea-leopards" in the Indian Ocean around Ceylon:

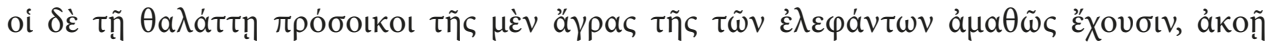

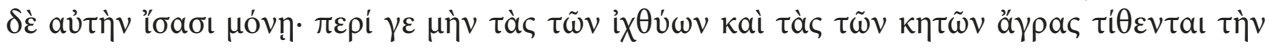

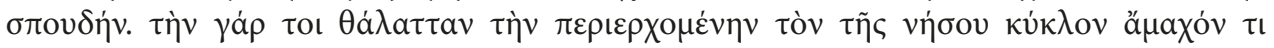

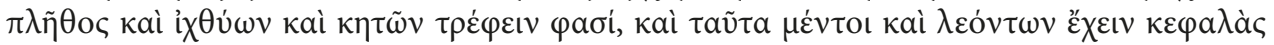

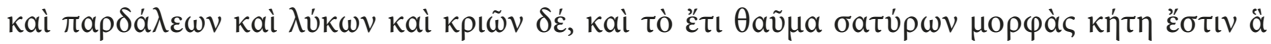

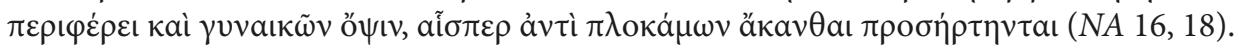

Whereas those that live near to the sea are ignorant of the way in which elephants are hunted and only know of it by hearsay: they devote themselves to catching fish and sea-monsters. For they assert that the sea which surrounds the circuit of their island [sc. Ta $\cos \beta \dot{\alpha} v \eta$, i.e. Ceylon] breeds a multitude past numbering of fishes and monsters, and moreover that they have the heads of lions and leopards and wolves and rams, and still more wonderful to relate, that there are some which have the forms of satyrs with the faces of women, and these have spines attached in place of hair. (Trans. by A. F. Scholfield. ${ }^{9}$ )

\footnotetext{
${ }^{5}$ Mair 1963, 241, 243.

6 Mair 1963, 460 (Greek text), 461 (English translation).

7 Scholfield 1959, II 267, 269.

${ }^{8}$ Schwanbeck 1846, 177 (Fr. incert. 59, 33-34).

9 Scholfield 1959, III 285.
} 
It is completely uncertain whether mysterious sea-monsters with leopard's head, existing in the Indian Ocean around Ceylon, should be identified with the Mediterranean sea-leopards or not. Still, it is not impossible to suggest that they are identical with the sea-leopards living in the Red Sea. In fact, the Red Sea is an inlet of the Indian Ocean. Generally, most species of fish and sea-animals, living in the Red Sea, appear in the Indian Ocean as well.

It is worth emphasizing that D'Arcy Wentworth Thompson gives two different meanings for the ichtyonym $\pi \alpha \dot{\rho} \delta \alpha \lambda ı$ c: 1 . 'a great, fierce fish, or sea-monster'; 2 . 'a fish of the Red Sea, spotted as a leopard.' ${ }^{10}$ Apparently, the scholar is not sure whether the sea-leopards living in the Mediterranean and the Red Sea represent the same species. It is highly probable, however, that the ancient writers describe the same cosmopolitan sea-fish of monstrous size, living both in the Atlantic Ocean (including the Mediterranean Sea) and the Indian Ocean (including the Red Sea).

Thompson gives no concrete identification of the fish in question, whereas Maria Chrone-Vakalopoulos and Angelos Vakalopoulos connect the sea-monster called $\pi \alpha \dot{\alpha} \delta \alpha \lambda ı \varsigma$ with the great white shark (Carcharodon carcharias L.). ${ }^{11}$ We cannot agree with the latter proposal for two reasons. Firstly, the great white shark was known as $\lambda$ á $\mu$ ia or $\lambda \alpha \dot{\mu} v a .{ }^{12}$ According to Nicander (Fr. 137, apud Ath. 7, 306d), ${ }^{13}$ the same fish was called

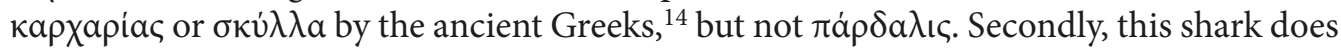
not have stained or spotted body, as every leopard has.

In our opinion, four compelling arguments allow to associate $\pi \dot{\alpha} \rho \delta \alpha \lambda ı$ with the sand tiger shark (Carcharias taurus Rafinesque, 1810), belonging to the family of sand sharks (Odontaspidae). ${ }^{15}$ These are:

1. The sand tiger shark is a large viviparous fish that fits the concept of $\kappa \tilde{\eta} \tau o \varsigma$. An adult shark commonly reaches three meters, maximally $4.5 \mathrm{~m} .{ }^{16}$ Its maximal weight can be around $200 \mathrm{~kg}$ (usually $100-150 \mathrm{~kg}$ ).

2. The fish Carcharias taurus (Rafinesque, 1810) lives - in agreement with Aelian's information ${ }^{17}$ - not only in the Mediterranean Sea, but also in the Indian Ocean, including the Red Sea. ${ }^{18}$

3. The sand tiger shark as a strong predatory fish with large, sharp teeth, is extremely gluttonous and dangerous for sea animals and even for people swimming in the shallow sea. Oppianus confirms the destructive characteristics of the sea-monsters in question

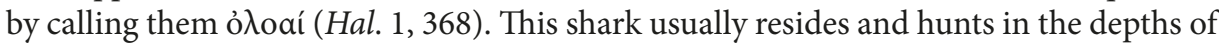
the sea, but also swims to the coast and sometimes attacks bathing people. The attacks of

10 Thompson 1936, 194.

11 Chrone-Vakalopoulos, Vakalopoulos 2008, 145.

12 Thompson 1936, 144; Dalby 2003, 299; Kokoszko 2005, 192-193.

13 Schneider 1856, 205; Kaibel 1887, II 175.

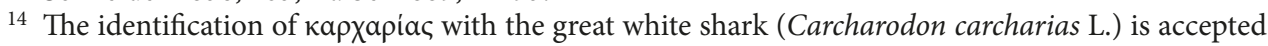
by Bartol, Danielewicz 2010, 583, fn. 467, as well as Smagowicz 2004, 100. According to Dalby (2003, 299), it "is possibly the porbeagle (Lamna nasus)". However, most researchers reach the conclusion that the shark called кархарiaৎ cannot be identified with certainty, cf. Thompson 1936, 106-107 ("A shark, of uncertain species"); de Saint-Denis 1947, 19 ("le squale aux dents aiguës, c.-à.-d. le requin”); Kokoszko 2005, 137-139; Montanari 2018, 1040 ('shark or a type of fish with sharp teeth').

15 Rutkowicz 1982, 130-131; Terofal, Militz 1986, 10-11; Nikiforos 2002, 66-67, tav. 5.2.

16 Rutkowicz 1982, 131.

17 Ael. NA 9, 49; 11, 24; 16, 18.

18 Rutkowicz 1982, 131. 


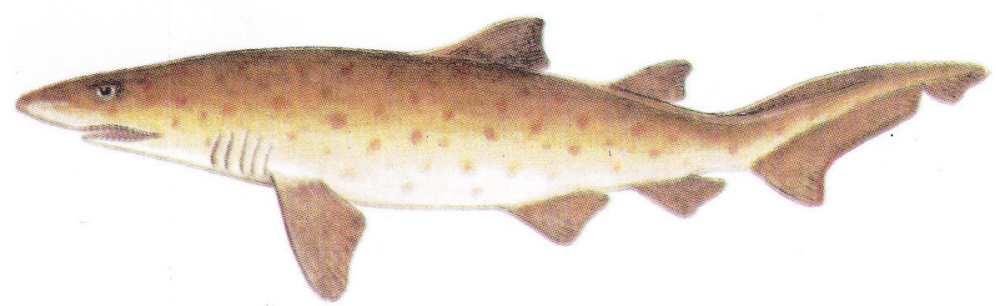

Fig. 1. The sand tiger shark or the spotted ragged-tooth shark (Carcharias taurus Rafinesque, 1810)

S o u r c e: Rutkowicz 1982, 130.

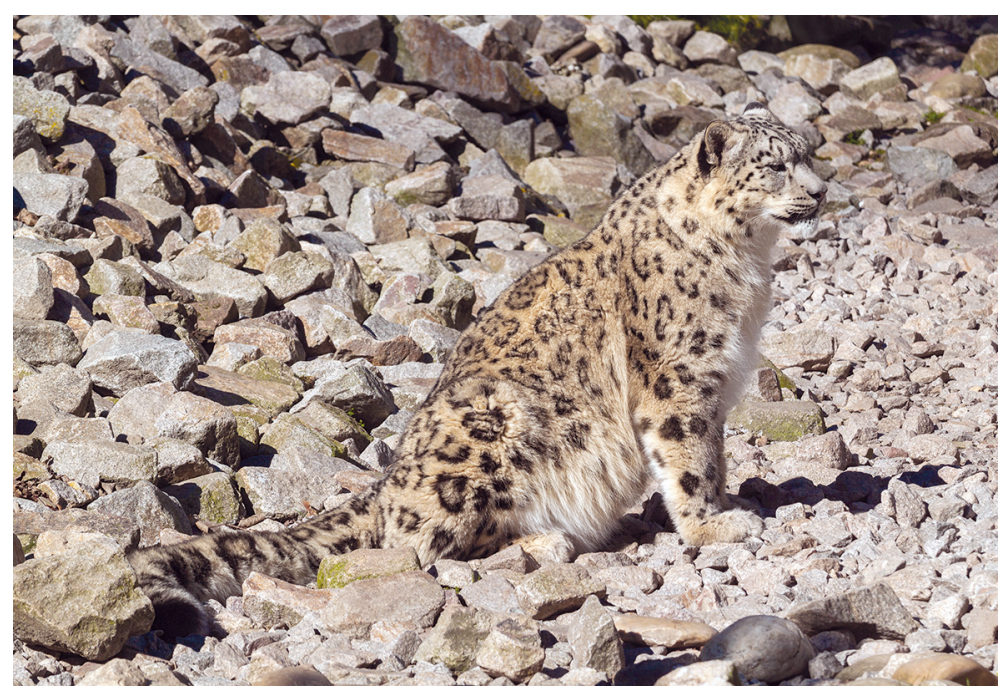

Fig. 2. The snow panther or the ounce (Panthera uncia, Schreber, 1775)

S o u r c e: https://commons.wikimedia.org/wiki/Panthera_uncia/media/File: Panthera_uncia_-_Zoo_Karlsruhe.jpg

the sand tiger sharks certainly had to happen in ancient times, so the fish was perfectly recognizable by the Greeks.

4. The sand tiger shark has a gray-pale back covered with round darker reddish-brown spots distributed evenly throughout the body (Fig. 1). Aelian indicates that the fish resembles ounce's body (Fig. 2) as to its colour and circular markings (

Hence, the identification of $\pi \alpha \dot{\alpha} \delta \alpha \lambda ı \varsigma_{\text {with }}$ the sand tiger shark presents itself. In fact, no other species can be taken into consideration.

\section{The Oxyrrhynchus fish}

According to Gościwit Malinowski, ${ }^{19}$ the ichthyonym ỏ $\xi \dot{v}(\rho) \rho v \gamma \chi 0 \varsigma$ denotes five species:

1. The Egyptian oxyrrhynchus, a freshwater fish living in the Nile (Str. 17, 1, 40; 1, 2, 4 etc.; Ael. NA 10, 46); it is commonly suggested that this fish belongs to the family

${ }^{19}$ Malinowski 2003, 231, fn. 60. 
Mormyridae. The identification with the Egyptian trunkfish (Mormyrus niloticus Bloch \& J. G. Schneider, 1801) seems the most probable.

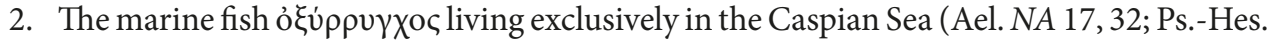
Fr. 372, 5-6, apud Ath. 3, 116b); ${ }^{20}$ it refers probably to the Persian sturgeon (Acipenser persicus Borodin, 1897) or some related species, e.g. starry sturgeon (Acipenser stellatus Pallas, 1771).

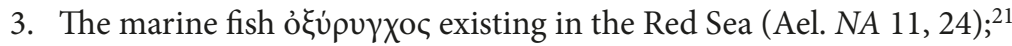

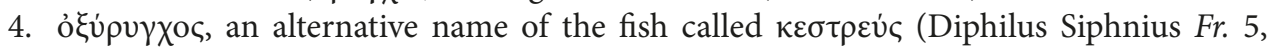
apud Ath. 7, 356a) ${ }^{22}$; according to Strabo, it represents an anadromous fish, which every spring swims up the river Nile to spawn. ${ }^{23}$ The fish is found and caught not only in the marine and brackish waters but also in freshwater lakes and rivers. It is identified with the flathead grey mullet (Mugil cephalus L., 1758). ${ }^{24}$

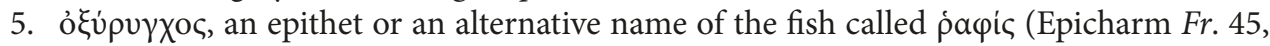
apud Ath. 7, 304c; 7, 319d): ${ }^{25}$ it is commonly identified as needlefish (Belone belone acus Risso, 1827), a member of the family Belonidae.

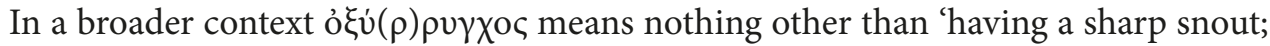
sharp-snouted, sharp-pointed. ${ }^{26}$ It is obvious, then, that every ichthyonym derived from this adjective implies a fish having a rostrum (like a sturgeon) or an elongated mouth (like a garfish). ${ }^{27}$

In the initially cited report Aelian describes the fish called ó $\dot{v} \rho v \gamma \chi 0 \varsigma$ rather carefully. To identify the species, the following premises are helpful:

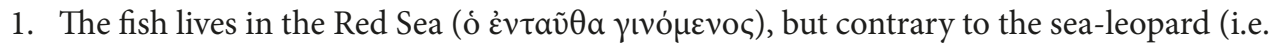
the sand tiger shark, as stated above) it is completely absent in the Mediterranean.

2. "An elongated mouth" ( $\pi \rho$ ó $\mu \kappa \varepsilon \varsigma$ tò $\sigma \tau$ tó $\mu \alpha)$.

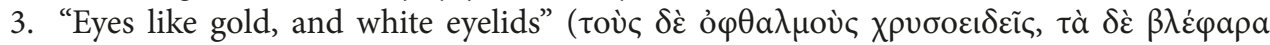
$\lambda \varepsilon v \kappa a ́)$.

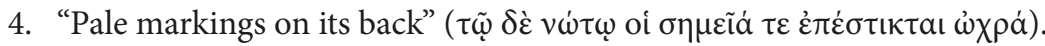

5. "The fins on its sides are black, while the dorsal fins are white" ( $\pi \tau \dot{\varepsilon} \rho v \gamma \varepsilon \varsigma$ aủ $\tilde{\omega}$ ai $\mu \varepsilon \dot{\varepsilon} v$

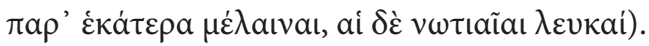

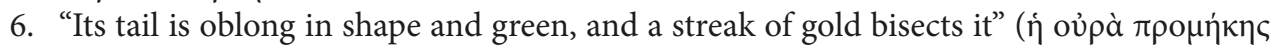

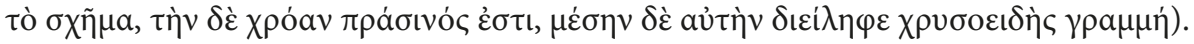

Point 3 above makes clear that the fish has the so-called nictitating membranes, i.e. transparent or translucent third eyelids, which additionally protect eyes. This is a rare anatomic structure among fish. It is exclusively exhibited by sharks belonging to the order Carcharhiniformes. ${ }^{28}$ The third eyelid covers the eye to help protect it, while the shark is

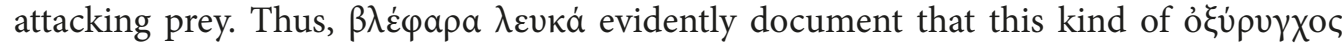
represents a species of shark.

20 Merkelbach, West 1967 (Fr. 372); Kaibel 1887, I 266.

21 Francesco Maspero $(1998,671)$ introduces “storione" [i.e. sturgeon], explaining his decision in fn. 45: "Traduciamo con «storione», anche se probabilmente si tratta di un pesce che gli somiglia".

22 García Lázaro 1982, 49-91, s.v. Diphilus Siphnius (Fr. 5); Kaibel 1887, II 279.

23 Strabo 17. 8. 23. See also Malinowski 2003, 226.

24 Thompson 1936, 108-110.

25 Kassel, Austin 1986, s.v. Epicharmus (Fr. 45); Kaibel 1887, II 170, II 203.

26 See LSJ s. v. and Montanari 2018, 1469.

27 Strömberg 1943, 43.

28 Gruber 1977, 454-455; Nayara Poscai et al. 2017, 359-364. 
Although Carcharhiniformes is the largest order of sharks including ca. $50 \%$ of all species currently described (509 species in general), ${ }^{29}$ it is not impossible to provide an identification of the oxyrrhynchus shark. Actually, only three species can be considered:

(A) the bignose shark (Carcharhinus altimus S. Springer, 1950), see Fig. $33^{30}$ it is a large predatory fish frequenting deep waters around the edges of the continental shelf. Males and females probably reach 2,6-2,8 $\mathrm{m}$ in length with the registered weight $168 \mathrm{~kg}$.

(B) the silky shark (Carcharhinus falciformis J.P. Müller \& Henle, 1839, syn. Carcharhinus menisorrah J. P. Müller \& Henle, 1839), see Fig. $4 ;^{31}$ the adult male shark reaches usually $2,5 \mathrm{~m}$ in length, females even 3-3,5 $\mathrm{m}$ (with the weight ca. 300-350 kg).

(C) the bull shark (Carcharhinus leucas J.P. Müller \& Henle, 1839), see Fig. 5. ${ }^{32}$ Adult females, which are larger than males, reach a maximum size of $3,5 \mathrm{~m}$ and the weight of $315 \mathrm{~kg}$. Larger bull sharks are probably responsible for most attacks on bathing people. $^{33}$

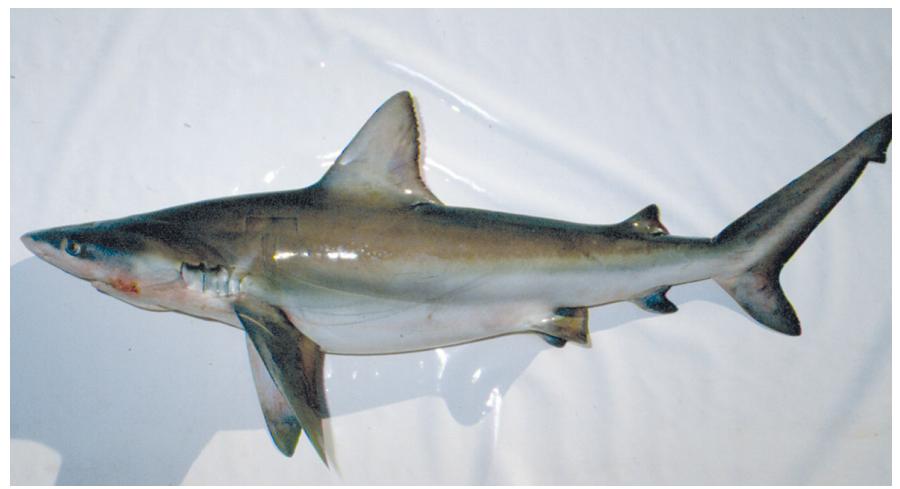

Fig. 3. Bignose shark (Carcharhinus altimus S. Springer 1950)

S o u r c e: https://commons.wikimedia.org/wiki/File:Carcharhinus_ altimus_nefsc.jpg

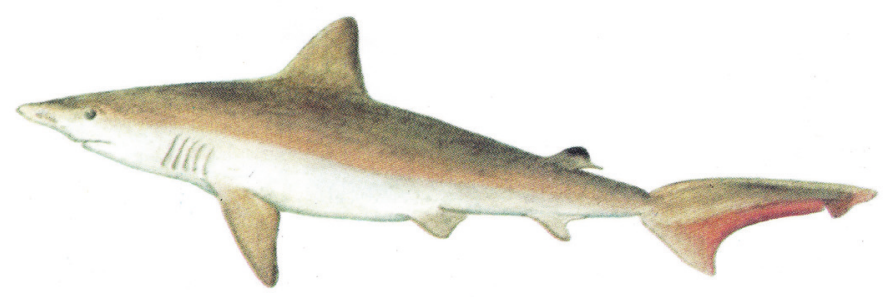

Fig. 4. Silky shark (Carcharhinus falciformis J. P. Müller \& Henle, 1839)

S o u r c e: Rutkowicz 1982, 136.

29 Weigmann 2016. See also Compagno 2005.

${ }^{30}$ Compagno 1984, 457-458; Nikiforos 2002, 66, tav. 5.10.

31 Rutkowicz 1982, 136-137, no. 23; Compagno 1984, 470-472; Nikiforos 2002, 66, tav. 5.16.

32 Rutkowicz 1982, 136-137, no, 22; Compagno 1984, 478-481.

33 Rutkowicz 1982, 137 ("Podobno atakuje kąpiących się ludzi, bywa więc niebezpieczny” [Apparently the bull shark attacks bathers, so it can be dangerous]). 


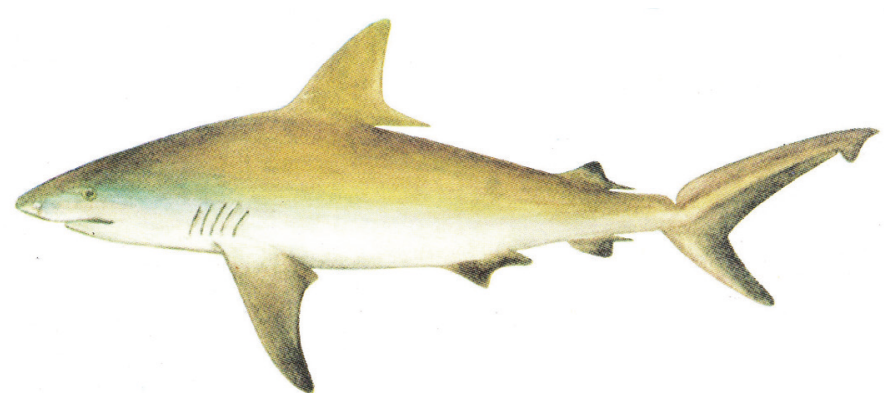

Fig. 5. Bull shark (Carcharhinus leucas J. P. Müller \& Henle, 1839).

S o u r c e: Rutkowicz 1982, 136.

Below we comment on Aelian's description (points 1-6 above) taking into account these three species.

1. The bignose sharks, the silky sharks and the bull sharks are well documented in the Red Sea. They do not belong to the typical Mediterranean fauna (though nowadays they sometimes flow into the Mediterranean Sea through the Suez Canal). The bignose sharks have been registered in the Spanish waters of the Mediterranean Sea. Two remaining species are generally absent in the Mediterranean Sea. The agreement with Aelian's description is complete.

2. The bignose shark has a long, broad, and bluntly pointed snout with the nostrils preceded by well-developed, triangular flaps of skin (Fig. 3). The English name, as well as the Russian one (Большеносая акула), expresses its prominent snout very well. The silky shark has also an elongated mouth (Fig. 4). The bull shark has a little less protruding snout. Aelian's description as well as the adjectival epithet oxyrrhynchus per se might refer to all three species, but the bignose shark seems to be a preferable option.

3. The bignose shark has relatively large, circular eyes equipped with protective third eyelids. The medium-sized eyes of the silky shark has nictitating membranes as well. ${ }^{34} \mathrm{It}$ is obvious, however, that $\beta \lambda \dot{\varepsilon} \varphi \alpha \rho \alpha \lambda \varepsilon v \kappa \alpha$ should be exhibited by the bull shark too, since it also belongs to the family Carcharhinidae.

4. The coloration of the bignose shark is gray to bronze on the back, with pale stripes on the flank and white below (Fig. 3). The silky shark has a pale-brown or dark gray back and the snowy white belly. The bull shark shows a similar body colour (see Fig. 5). It is evident that each of the three species presents "pale markings on its back".

5. "Black fins on the sides and white dorsal fins" create a problem, since no species of shark has white dorsal fins. In fact, most sharks have a white or whitish belly. Still, their lower fins present a dark or black colour on the upper side and the white colour on the lower side (Fig. 6). That could explain the black-white opposition. If this is correct, the feature is equally characteristic not only of the silky shark (Fig. 6), but also of the bignose shark and of the bull shark.

6. The last passus of Aelian's description refers to the caudal peduncle of the oxyrrhynchus. All three species of sharks have a fairly high caudal fin accompanied by a well-developed lower lobe. Their tail may be green, blue-green, blue-gray, brown or even black in

34 Rutkowicz 1982, 137: “oczy z przesłoną migawkową" [eyes with nictitating membranes]. 


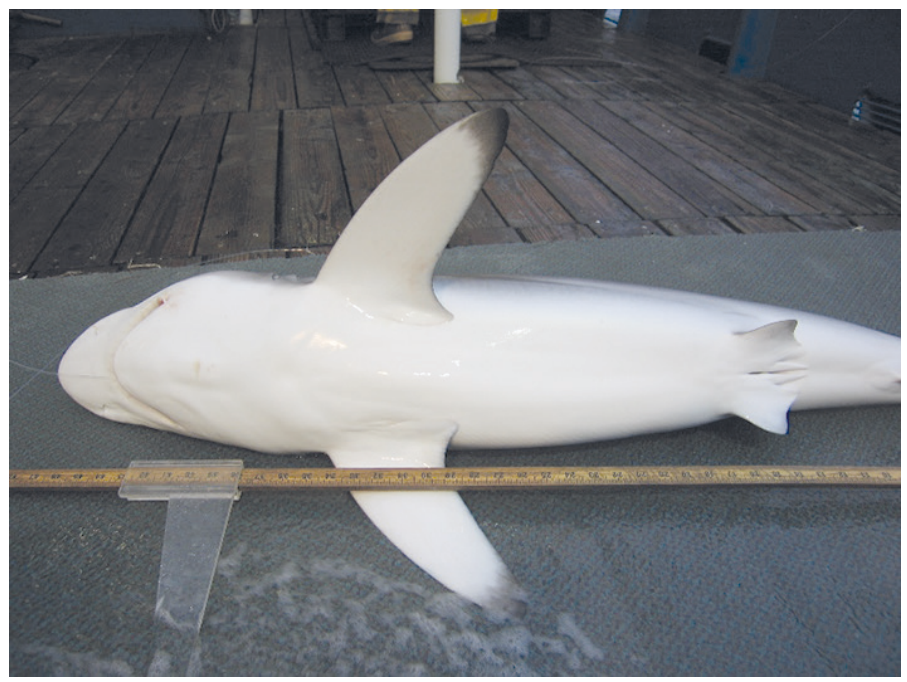

Fig. 6. The big pectoral fins and small pelvic fins of the silky shark

S o u r c e: https://commons.wikimedia.org/wiki/File:Carcharhinus_ falciformis_piro4.jpg

colour. ${ }^{35}$ A strong (usually golden-pale or whitish) ventral notch is seen in the caudal fins of all three analyzed sharks. Regardless of whether Aelian's words describe the bignose shark, as they seem to do it (see Fig. 3), or refer to the other two species, the presentation meets the point precisely.

The detailed analysis of all possible data logically brings to the assumption that

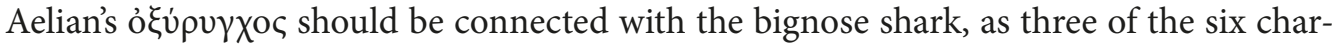
acteristics (big nose, pale colour and green tail) coincide with confirm this species. Of course, it is also possible that the ancients were unable to distinguish exactly the sharks belonging to the family Carcharhinidae (requiem sharks). If so, the Greek term ỏ ípv $\gamma \chi 0 \varsigma$ could be used for all three aforesaid species.

\section{References}

Bartol K., Danielewicz J. Atenajos, Uczta mędrców. Poznań, Wydawnictwo Poznańskie, 2010.

Beekes R. Etymological Dictionary of Greek. Leiden — Boston, Brill, 2010.

Chrone-Vakalopoulos M., Vakalopoulos A. Fishes and Other Aquatic Species in Byzantine Literature: Classification, Terminology and Scientific Names. Byzantina Symmeikta 2008, 18, 123-157.

Compagno L. J. V. The FAO Species Catalogue, vol. 4: Sharks of the World, Part 2: Carcharhiniformes. Rome, Food and Agriculture Organization of the United Nations, 1984.

Compagno L. J. V. Checklist of living Chondrichthyes, in: W. C. Hamlett (ed.) Reproductive biology and phylogeny of Chondrichthyes: sharks, batoids and chimaeras. New York, Science Publishers, 2005, 501-548.

Dalby A. Food in the Ancient World from A to Z. London - New York, Routledge, 2003.

35 One of two anonymous reviewers correctly stresses that only the bignose shark has "a green sheen along the gills of freshly collected specimens", see Fig. 2 and the profile of this shark on the site of the Florida Museum of Natural History: https://www.floridamuseum.ufl.edu/discover-fish/species-profiles/ carcharhinus-altimus/. It seems to be an additional argument for the identification of Aelian's oxyrrhynchus fish with the bignose shark. 
Fajen F. (ed.) Oppianus, Haleutica / Oppian, Der Fischfang. Stuttgart - Leipzig, Teubner, 1999.

García Lázaro C. Medici Graeci apud Athenaeum tantum servati. Madrid, Universidad Complutense, 1982.

García Valdés M., Llera Fueyo L. A., Rodríguez-Noriega Guillén L. Claudius Aelianus, De natura animalium. Berolini - Novi Eboraci, De Gruyter, 2009.

Gruber S. H. The Visual System of Sharks: Adaptations and Capability. American Zoology 1977, 17, 453-469.

Kaibel G. (ed.) Dipnosophistarum libri XV, vol. I. Lipsiae, Teubner, 1887.

Kassel R., Austin C. Poetae Comici Graeci. Vol. V: Damaxenus-Magnes. Berlin - New York, De Gruyter, 1986.

Kokoszko M. Ryby i ich znaczenie w życiu codziennym ludzi późnego antyku i wczesnego Bizancjum (IIIVII w.). Łódź, Wydawnictwo Uniwersytetu Łódzkiego, 2005.

Kurek E. The Image of кñтoৎ in Oppian of Cilicia’s. Halieutica. Scripta Classica 2010, 7, 55-62.

Mair A. W. Oppian, Colluthus, Tryphiodorus. London, William Heinemann, 1963.

Malinowski G. Zwierzęta świata antycznego. Studia nad Geografią Strabona. Wrocław, Wydawnictwo Wrocławskiego, 2003.

Maspero F. (ed.) Claudio Eliano. La natura degli animali. Milano, Rizzoli, 1998.

Merkelbach R., West M. L. Fragmenta Hesiodea. Oxford, Clarendon Press, 1967.

Montanari F. The Brill Dictionary of Ancient Greek. Leiden - Boston, Brill, 2018.

Nayara Poscai A., de Sousa Rangel B. et al. Microscopic aspects of the nictitating membrane in Carcharhinidae and Sphyrnidae sharks: a preliminary study. Zoomorphology 2017, 136 (3), 359-364.

Nikiforos G. Fauna del Mediterraneo. Firenze, Giunti, 2002.

Rutkowicz S. Encyklopedia ryb morskich. Gdańsk, Wydawnictwo Morskie, 1982.

Saint-Denis E. de Le vocabulaire des animaux marins en latin classique. Paris, Klincksieck, 1947.

Schneider I. G. (ed.) Oppiani Cynegetica et Halieutica. Lipsiae, Weigel, 1813.

Schneider O. (ed.) Nicandrea: Theriaca et Alexipharmaca. Leipzig, Teubner, 1856.

Scholfield A.F. (ed.) Aelian, On the Characteristics of Animals, vol. II-III.London, William Heineman Cambridge, Ma, HUP, 1959.

Schwanbeck E. A. (ed.) Megasthenis Indica. Bonnae, Pleimesius, 1846.

Smagowicz K. Mantichora. Etymologiczny słownik nazw zwierząt. Kraków, Wydawnictwo Uniwersytetu Jagiellońskiego, 2004.

Strömberg R. Studien zur Etymologie und Bildung der griechischen Fischnamen. Göteborg, Elanders Boktryckeri Aktiebolag, 1943.

Terofal F., Militz C. Meeresfische in europäischen Gewässern. München, Mosaik Verlag, 1986.

Thompson A. W. Glossary of Greek Fishes. London, OUP, 1936.

Weigmann S. Annotated Checklist of the Living Sharks, Batoids and Chimaeras (Chondrichthyes) of the World, with a Focus on Biogeographical Diversity. Journal of Fish Biology 2016, 88 (3), 837-1037.

Received: August 09, 2019

Accepted: February 19, 2020 